\title{
Circulating amino acids in blood plasma during the peripartal period in dairy cows with different liver functionality index
}

\author{
Z. Zhou, ${ }^{*}$ J. J. Loor, ${ }^{* 1}$ F. Piccioli-Cappelli,† F. Librandi,‡ G. E. Lobley,§ and E. Trevisi $\dagger^{1}$ \\ *Mammalian NutriPhysioGenomics, Department of Animal Sciences and Division of Nutritional Sciences, University of Illinois, Urbana 61801 \\ †Istituto di Zootecnica Facoltà di Scienze Agrarie, Alimentari e Ambientali, Università Cattolica del Sacro Cuore, 29122, Piacenza, Italy \\ łlspettorato Centrale della Tutela della Qualità, Ministry of Agricultural, Food and Forestry Policies (MIPAAF), 00187, Rome, Italy \\ §Rowett Institute of Nutrition and Health, University of Aberdeen, Greenburn Road, Bucksburn, Aberdeen, AB21 9SB, United Kingdom
}

\begin{abstract}
The liver functionality index (LFI) measures the changes of albumin, cholesterol, and bilirubin concentrations between 3 and $28 \mathrm{~d}$ postpartum. This composite index, based on variables with direct relevance to liver-specific plasma protein synthesis (albumin), hepatic/intestinal lipoprotein synthesis (cholesterol), and clearance of breakdown products of heme catabolism (bilirubin), provides a tool for evaluating manifestations of hepatic disease. Both energy and protein metabolism are likely to be affected by various physiological challenges in this period but have not been tested systematically. The present study was conducted to profile AA in cows with high or low LFI during the peripartal period and relate this to production outcomes. Eighteen multiparous cows were used from -21 through $28 \mathrm{~d}$ around parturition and divided retrospectively into the high or low LFI group. Blood samples were obtained on -21 , $-14,-7,1,3,7,10,14,17,21$, and $28 \mathrm{~d}$ relative to calving, and biomarkers and AA in plasma were measured. Grouping based on LFI resulted in 8 cows with high LFI (HLFI) and 10 cows with low LFI (LLFI). Although the temporal response in dry matter intake (DMI, $16.3 \mathrm{~kg} / \mathrm{d}$ ) and body condition score (2.56) did not differ, cows with high compared with low LFI had greater overall milk production (37.9 vs. $32.9 \mathrm{~kg} / \mathrm{d}$ ) although energy-corrected milk yield did not differ (42.6 vs. $38.7 \mathrm{~kg} / \mathrm{d}$ ). As expected, cows grouped as LLFI had lower cholesterol and albumin but greater bilirubin after calving compared with HLFI animals. Despite similar temporal responses in DMI between groups, concentrations of total AA were greater in HLFI, particularly after calving. Although concentrations of total essential AA (EAA) and branched-chain AA did not differ with LFI status, cows in HLFI had greater concentrations of Thr and Ile postpartum. Nearly all plasma AA con-
\end{abstract}

\footnotetext{
Received May 11, 2015.

Accepted November 23, 2015

${ }^{1}$ Corresponding authors: jloor@illinois.edu and erminio.trevisi@ unicatt.it
}

centrations followed the general trend of a nadir at $1 \mathrm{~d}$ after calving followed by a gradual increase to prepartal levels before $28 \mathrm{~d}$. Glycine was the only AA exhibiting a gradual increase in concentration through the transition, with a maximum at $7 \mathrm{~d}$ postpartum followed by a gradual decrease. We detected no effect of LFI status on plasma Lys, which decreased markedly from $-21 \mathrm{~d}$ to calving, followed by an increase to prepartal values by d 7 . In contrast, concentrations of Met and His decreased markedly between -21 and $10 \mathrm{~d}$ and did not reach prepartal values by $28 \mathrm{~d}$. The marked decrease in Gln concentration after calving regardless of LFI might compromise immune function during this period. Overall, the results indicate the existence of an association among inflammation, liver function postpartum, and AA plasma concentrations, irrespective of temporal differences in DMI. Cows with better indices of liver function produced more milk and maintained greater concentrations of total AA and some EAA such as Thr and Ile. Whether these AA played a direct role in the greater milk production remains to be determined.

Key words: transition period, nutrition, liver function, amino acid metabolism

\section{INTRODUCTION}

The periparturient or transition period, defined as 3 wk before through 3 wk after parturition, is the most challenging period of the lactation cycle (Drackley, 1999). Cows are susceptible to various health complications during this time because of marked changes in endocrine status and immunosuppression, followed by decreased feed intake (Mallard et al., 1998; Drackley, 1999). Inflammatory responses occur during the periparturient period and may impair liver function and performance of dairy cows even without serious infections or other pathologies (Bionaz et al., 2007; Bertoni et al., 2008). Therefore, multiple indices have been proposed to assess the metabolic, immune, and inflammatory status of dairy cows in the periparturient period (Bertoni and Trevisi, 2013). 
Using changes in plasma concentrations of albumin, cholesterol, and bilirubin, the liver functionality index (LFI) characterizes the extent of the inflammatory response and helps predict its likely consequences on health and well-being of the cow (Bertoni and Trevisi, 2013). Previous work utilizing blood and milk samples has confirmed the usefulness of this approach to assess immune and inflammatory status (Trevisi et al., 2010b). For instance, a low LFI (LLFI) value is indicative of a pronounced inflammatory response, suggestive of a more difficult transition from gestation to lactation, whereas a high LFI (HLFI) is suggestive of a smooth transition (Trevisi et al., 2012).

Other than the synthesis of acute-phase proteins (APP) such as haptoglobin and ceruloplasmin, both the needs of the fetus prepartum and the needs of the mammary gland postpartum greatly increase the demand for AA. It is known, however, that supplies of $\mathrm{MP}$ and EAA are limiting around calving (Bell et al., 2000). Therefore, cows that adapt more successfully to the onset of lactation may have a better AA plasma profile. Only a few studies have attempted to characterize the AA profile during the periparturient period (Verbeke et al., 1972; Meijer et al., 1995; Doepel et al., 2002; Maeda et al., 2012; Hailemariam et al., 2014) and none in the context of LFI. Therefore, the hypothesis examined in the current study was that AA profiles would differ between cows with HLFI and LLFI.

\section{MATERIALS AND METHODS}

This study complied with Italian laws on animal experimentation and ethics.

\section{Animal Management and Experimental Design}

The experiment was carried out in the tiestall barn of the Istituto di Zootecnica (Piacenza, Italy) using 18 multiparous Holstein Friesian cows (average lactation number of $3.22 \pm 1.11$ ). During the dry period, all cows received the same diet prepartum: 6 to $8 \mathrm{~kg}$ of corn silage, $2 \mathrm{~kg}$ of dehydrated alfalfa, 9 to $10 \mathrm{~kg}$ of dehydrated grass, and $1 \mathrm{~kg}$ of concentrate. From $7 \mathrm{~d}$ before calving to calving, cows received an additional $1 \mathrm{~kg}$ of concentrate. From calving through 30 DIM, cows received a diet containing corn silage, increased at a rate of $2 \mathrm{~kg}$ every $4 \mathrm{~d}$ up to a maximum of 20 to $22 \mathrm{~kg}, 3 \mathrm{~kg}$ of dehydrated alfalfa, $2 \mathrm{~kg}$ of dehydrated grass, and a concentrate mix increased at a rate of 0.5 $\mathrm{kg}$ daily up to a maximum of 12 to $14 \mathrm{~kg}$.

Feed intake of individual cows was measured daily. Gross analysis and nutritive value of feeds were evaluated in representative samples collected twice a week for forages, and every $2 \mathrm{wk}$ for corn silage and the concentrate. Chemical composition of the feeds was determined using standard procedures (AOAC International, 2000). Body weight was measured every $2 \mathrm{wk}$ throughout the study and BCS was estimated. Milk yield at each milking was weighed and recorded from calving to 30 DIM. Based on milk sample analysis, the ECM (at 3.5\% fat) was calculated as follows: $\mathrm{ECM}=$ $[12.82 \times$ fat yield $(\mathrm{kg})]+[7.13 \times$ protein yield $(\mathrm{kg})]+$ [0.323 $\times$ milk yield $(\mathrm{kg})]$ (Hutjens, 2010).

The LFI was determined for all cows based on plasma concentrations of albumin, cholesterol, and bilirubin, as described in Bertoni and Trevisi (2013), and used to rank the cows retrospectively. The LFI calculation is carried out in 2 steps; the first considers the concentration values $(\mathbf{V})$ of the 3 parameters detected on $\mathrm{d} 3$ (V3) and changes in concentrations between d 3 and 28 (V28). The albumin and cholesterol indices were calculated as $0.5 \mathrm{~V} 3+0.5(\mathrm{~V} 28-\mathrm{V} 3)$. The bilirubin index was calculated as $0.67 \mathrm{~V} 3+0.33$ (V28 - V3), with bilirubin level on d 3 postpartum representing $67 \%$ and the reduction between $\mathrm{d} 3$ and 28 the remaining $33 \%$ of the partial LFI index. In the second step, these partial indices were standardized according to average values observed in "healthy" cows within the same herd, and LFI was calculated according to the following formula: $\mathrm{LFI}=[($ albumin index -17.71$) / 1.08+($ cholesterol index -2.57$) / 0.43-$ (bilirubin index -6.08$) / 2.17]$. Cows with a positive LFI (mean: $1.65 \pm 0.11$ ) were considered as the HLFI group and cows with negative LFI (mean: $-3.69 \pm 0.64$ ) were considered as the LLFI group.

\section{Blood Sampling and Analysis}

Blood samples were collected before concentrate and forages were offered at $0700 \mathrm{~h}$ from the jugular vein into heparinized vacuum tubes on $-21,-14,-7,1$, $3,7,10,14,17,21$, and $28 \mathrm{~d}$ relative to calving. After collection, tubes were placed on ice and plasma was obtained by centrifugation at $1,900 \times g$ for $15 \mathrm{~min}$ at $4^{\circ} \mathrm{C}$. Aliquots of plasma was frozen $\left(-20^{\circ} \mathrm{C}\right)$ until further analysis. Metabolic biomarkers [haptoglobin, ceruloplasmin, Zn, Ca, globulin, albumin, cholesterol, bilirubin, $\gamma$-glutamyl transpeptidase (GGT), lactate dehydrogenase, $\gamma$-glutamyl transpeptidase (GOT), glucose, fatty acids, BHB, triglycerides, urea, creatinine, $\mathrm{Mg}, \mathrm{Na}, \mathrm{Cl}, \mathrm{K}$, and $\mathrm{P}]$ were analyzed by methods described in Piccioli-Cappelli et al. (2014).

Concentrations of AA (Ala, Gly, Val, Leu, Ile, Pro, Met, Ser, Thr, Phe, Asp, Cys, Glu, Lys, His, Gln, Tyr, Trp) were determined in plasma samples at the Rowett Institute for Nutrition and Health (Aberdeen, UK) by isotope dilution coupled with GC-MS (Calder et al., 1999). The area under the curve (AUC) approach 
is routinely used to incorporate multiple time points for statistical comparisons (Pruessner et al., 2003). In terms of plasma AA or other metabolite responses, AUC is a valid approach not only in humans (Kume et al., 2014) but also in studies with dairy cows (Cardoso et al., 2011; Forde et al., 2014; McCarthy et al., 2015). Therefore, considering the large changes in plasma AA concentration over time around the transition period, AUC were calculated for each cow for statistical comparisons, in addition to the more traditional repeatedmeasures analysis of the normalized data. The prepartal and postpartal trapezoidal AUC were calculated by multiplying the mean of AA concentrations between 2 consecutive times of sampling and the duration of interval between the samplings.

\section{Statistical Analysis}

Data were analyzed by using the MIXED procedure of SAS 9.3 (SAS Institute Inc., Cary, NC). Each variable was evaluated for normal distribution using the Shapiro-Wilk test and normalized by logarithmic transformation when necessary before statistical analysis. Only Ser, His, total AA, Cl, Zn, and albumin did not require normalization. The model for the time-course data analysis contained LFI, day, and their interactions as fixed effects, and cow nested within LFI as random effect. A spatial power $(\mathrm{SP}=\mathrm{POW})$ covariance structure was used. Denominator degrees of freedom were computed using the DDFM $=\mathrm{KR}$ statement in SAS. The model for the separate analysis of prepartal and postpartal log-transformed data (Table 2, Supplemental Table S1; http://dx.doi.org/10.3168/jds.2015-9805) was the same as described above. Prepartal and postpartal AUC data were also analyzed using this model without repeated measures to incorporate multiple time points. Differences in postpartal cumulative DMI were analyzed using a model with LFI as fixed effect and cow nested within LFI as random effect. Least squares means separation between time points or treatments was performed using the PDIFF statement. To determine whether the differences in AA profiles and the grouping according to high and low LFI were confounded by differences in DMI or BCS prepartum, the DMI and BCS before calving were included as covariates when a significant difference $(P<0.05)$ in plasma AA in response to LFI was detected. However, as neither of the covariates was significant $(P>0.05)$, they were not included in the final statistical model. Data in tables and figures are presented as least squares means (LSM); however, for those data that required log-transformation, we report the nontransformed LSM and standard errors of the mean (SEM) for ease of evaluation and interpretation. Post hoc comparisons between treatments are discussed when the $P$-value for interaction or main effect was $\leq 0.05$. Main effects or interactions at $P \leq 0.15$ are discussed in the context of tendencies.

\section{RESULTS}

\section{Animal Performance}

No clinical disorders were detected in cows from both cohorts. The average lactation number for the 2 cohorts of cows was $3.38 \pm 1.41$ for HLFI cows and $3.10 \pm 0.88$ for the LLFI cows. Although a tendency $\left(P_{\mathrm{LFI}} \times\right.$ day $=$ 0.08 ) for an interaction on d 28 for greater DMI in HLFI cows was detected, the temporal response of DMI in daily $\left(P_{\mathrm{LFI}} \times\right.$ day $=0.95$; Figure 1$)$ and cumulative (postpartal $P_{\mathrm{LFI}}=0.15 ; 128 \pm 5.5 \mathrm{~kg}$ for HLFI and $116 \pm 5 \mathrm{~kg}$ for LLFI) DMI did not differ between the 2 cohorts of cows. Despite similar temporal DMI pre- and postpartum, HLFI cows produced more milk $\left(P_{\mathrm{LFI}} \times\right.$ day $=0.01$, Figure 1), especially during d 14 through 28 of lactation. A significant LFI $\times$ day interaction was detected for BW $\left(P_{\mathrm{LFI}} \times\right.$ day $\left.<0.01\right)$ and a tendency $\left(P_{\mathrm{LFI}} \times\right.$ day $\left.=0.07\right)$ for BCS (Supplemental Figure S1; http://dx.doi.org/10.3168/jds.2015-9805). Data for ECM, milk protein percentage, and milk fat percentage are reported in Supplemental Figure S2.

\section{Biomarkers of Inflammation, Liver Function, and Energy Balance}

For the selection criteria of LFI grouping, absolute and temporal differences were as expected. Globulin values were higher for the LLFI group both pre- and postcalving $\left(P_{\mathrm{LFI}}=0.04\right)$ but decreased until $\mathrm{d}-1$ and increased thereafter $\left(P_{\text {day }}<0.01\right)$. Bilirubin and albumin were constant before parturition with no differences between the LFI groups. After parturition, bilirubin increased $\left(P_{\text {dav }}<0.01\right)$ for both groups but to a greater extent in LLFI cows $\left(P_{\mathrm{LFI}}=0.03\right)$, particularly during the first $14 \mathrm{~d}$ after birth. In contrast, plasma albumin declined slightly for LLFI cows after calving but increased markedly for the HLFI animals $\left(P_{\mathrm{LFI}} \times\right.$ day $\left.=0.01\right)$.

Ceruloplasmin (Figure 2) had a similar tendency as globulin, with values lower for HLFI cows during the whole study $\left(P_{\mathrm{LFI}}=0.09\right)$ and increasing after birth for both cohorts $\left(P_{\text {day }}<0.01\right)$. Plasma cholesterol tended to increase more postpartum in HLFI cows $\left(P_{\mathrm{LFI}} \times\right.$ day $=$ 0.08 ; Figure 2).

No effect of LFI was detected for GOT but concentrations increased $\left(P_{\text {day }}<0.01\right)$ after calving for both cohorts (Supplemental Table S2; http://dx.doi. org/10.3168/jds.2015-9805). For glutamic oxaloacetic 

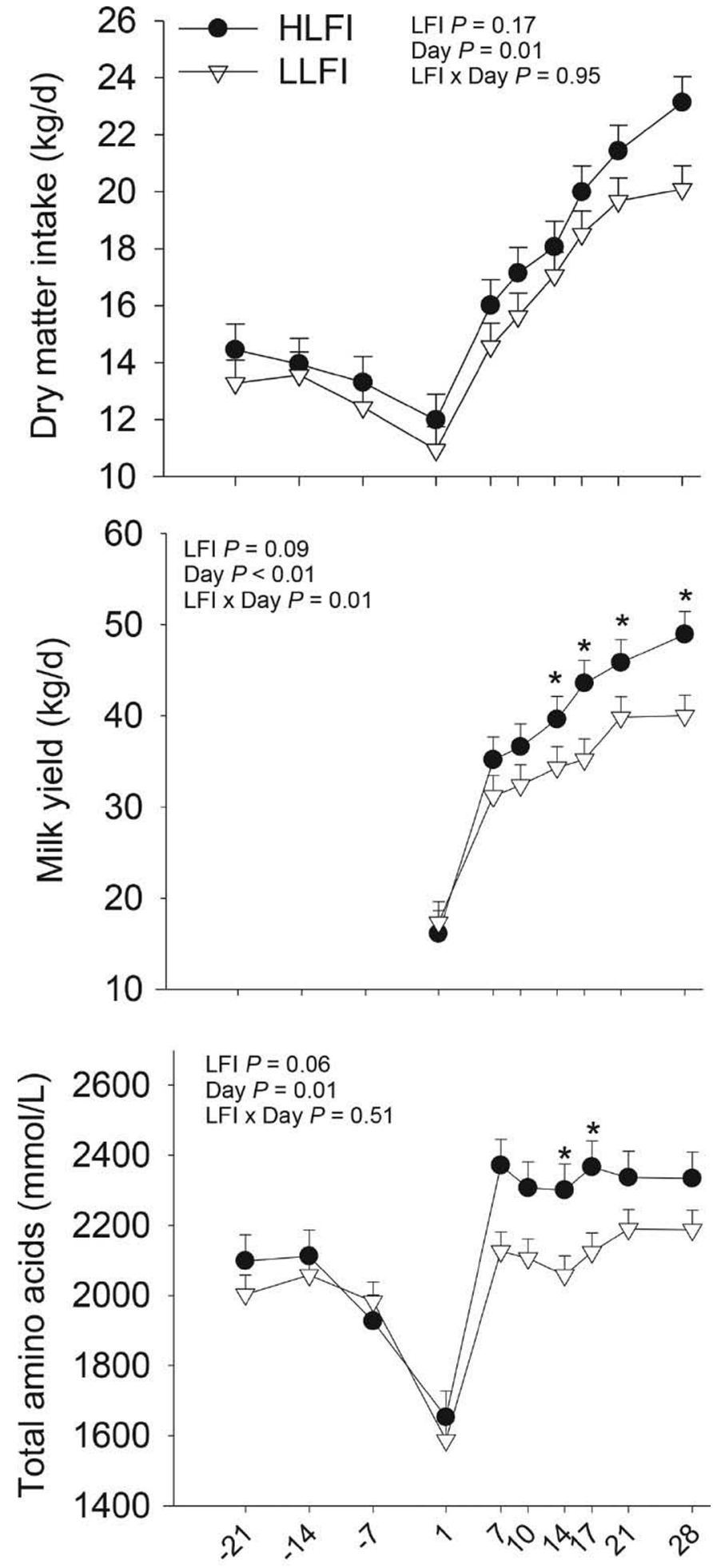

Day relative to parturition

Figure 1. Dry matter intake, milk yield, and blood plasma concentration of total AA during the periparturient period in cows retrospectively grouped into high (HLFI) and low (LLFI) liver functionality index (LFI). Values are LSM + SEM. ${ }^{*}$ LSM differ by $P<0.05$ (LFI $\times$ day). transaminase, although values for both groups increased $\left(P_{\text {day }}<0.01\right)$ after calving and returned to the values prepartum by $28 \mathrm{~d}$, the effect was greater for LLFI cows during the first week postcalving $\left(P_{\mathrm{LFI}} \times\right.$ day $\left.=0.01\right)$ compared with HLFI cows. Concentrations of fatty acids and BHB were not affected by LFI $\left(P_{\mathrm{LFI}}>0.15\right.$; Supplemental Table S2; http://dx.doi.org/10.3168/ jds.2015-9805). As expected, both fatty acids and BHB increased around d $1\left(P_{\text {day }}<0.01\right)$. Estimates of dietary net energy, MP content, small intestine availability of EAA, Met, and Lys (Supplemental Table S3; http:// dx.doi.org/10.3168/jds.2015-9805), DMI as a function of metabolic BW, efficiency of milk yield (Supplemental Table S4; http://dx.doi.org/10.3168/jds.20159805), and chemical composition of diets fed to cows (Supplemental Table S5; http://dx.doi.org/10.3168/ jds.2015-9805) are reported in the supplemental files.

\section{AA Profiles}

The analysis of the pre- and postpartal data together is reported in Table 1 and for selected AA in Figures 2,3 , and 4 . To better capture the potential effect of LFI, statistical analysis was also conducted separately for prepartum and postpartum periods with log-transformed data (Table 2, Supplemental Table S1; http:// dx.doi.org/10.3168/jds.2015-9805), and by calculating the AUC (Supplemental Table S6; http://dx.doi. org/10.3168/jds.2015-9805). Results from the AUC analysis agree with the analysis of log-transformed data (Table 2, Supplemental Tables S1 and S6) When evaluating prepartal data alone, except for a tendency for Glu $\left(P_{\mathrm{LFI}}=0.11\right.$; Supplemental Table S1), it was evident that AA concentrations did not differ with LFI status $\left(P_{\mathrm{LFI}}>0.15\right)$. When evaluating the postpartal data alone (Table 2, Supplemental Tables S1 and S6), compared with LLFI cows, the HLFI cows had greater total AA (TAA; $\left.P_{\text {LFI }}=0.02\right)$, branched-chain AA $\left(\right.$ BCAA; $\left.P_{\mathrm{LFI}}=0.03\right)$, and EAA $\left(P_{\mathrm{LFI}}=0.04\right)$ concentrations postpartum (Table 2, Supplemental Table S6). Thus, these responses account for the statistical tendencies detected for LFI when the data were analyzed together (Table 1).

Among all AA analyzed, the concentrations of Ile $\left(P_{\mathrm{LFI}}=0.01\right)$ and $\operatorname{Thr}\left(P_{\mathrm{LFI}}=0.02\right)$ were the most affected by LFI (Figure 3 ) with the responses most evident after calving $\left(P_{\text {day }}<0.01\right)$ in cows with HLFI (Table 2 ). Concentration of Gln (Figure 2) had a significant LFI $\times$ day interaction $\left(P_{\mathrm{LFI}} \times\right.$ day $\left.=0.04\right)$, in large part because of the marked decrease in concentration after calving within LFI (and more drastically in LLFI cows) but also because cows in HLFI compared with LLFI had greater concentrations on d 17 and 21 postpartum. When evaluating postpartal data alone, concentration 

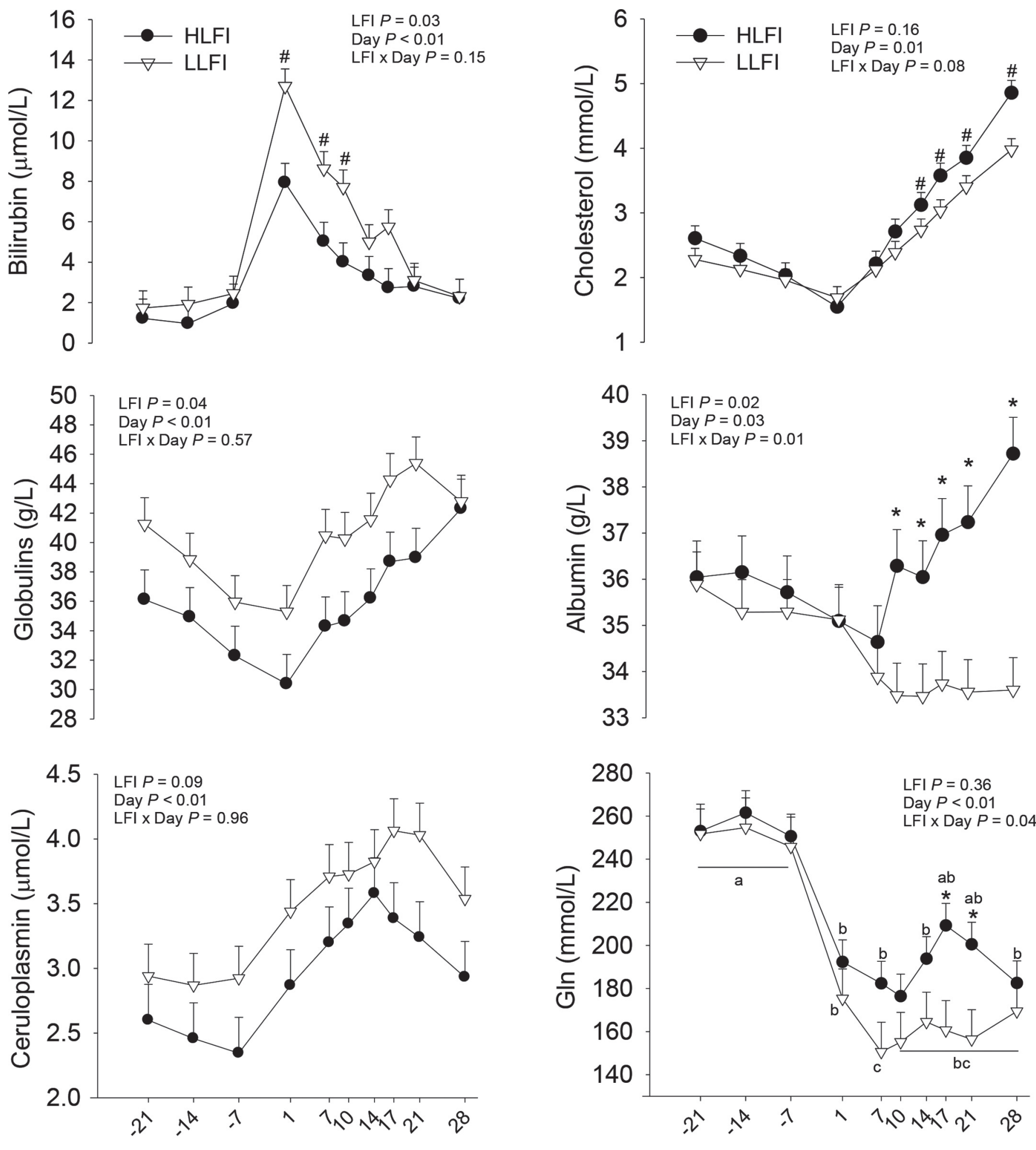

Day relative to parturition

Day relative to parturition

Figure 2. Blood plasma concentrations of bilirubin, globulin, cholesterol, albumin, ceruloplasmin, and Gln during the periparturient period in cows retrospectively grouped into high (HLFI) and low (LLFI) liver functionality index (LFI). Values are LSM + SEM. *LSM differed by $P<0.05$ (LFI $\times$ day) or \#tended to differ by $P<0.08$ (LFI $\times$ Day). Values with different letters $(\mathrm{a}-\mathrm{c})$ indicate that LSM between times and within LFI (LFI $\times$ day effect) differ by $P<0.05$. 


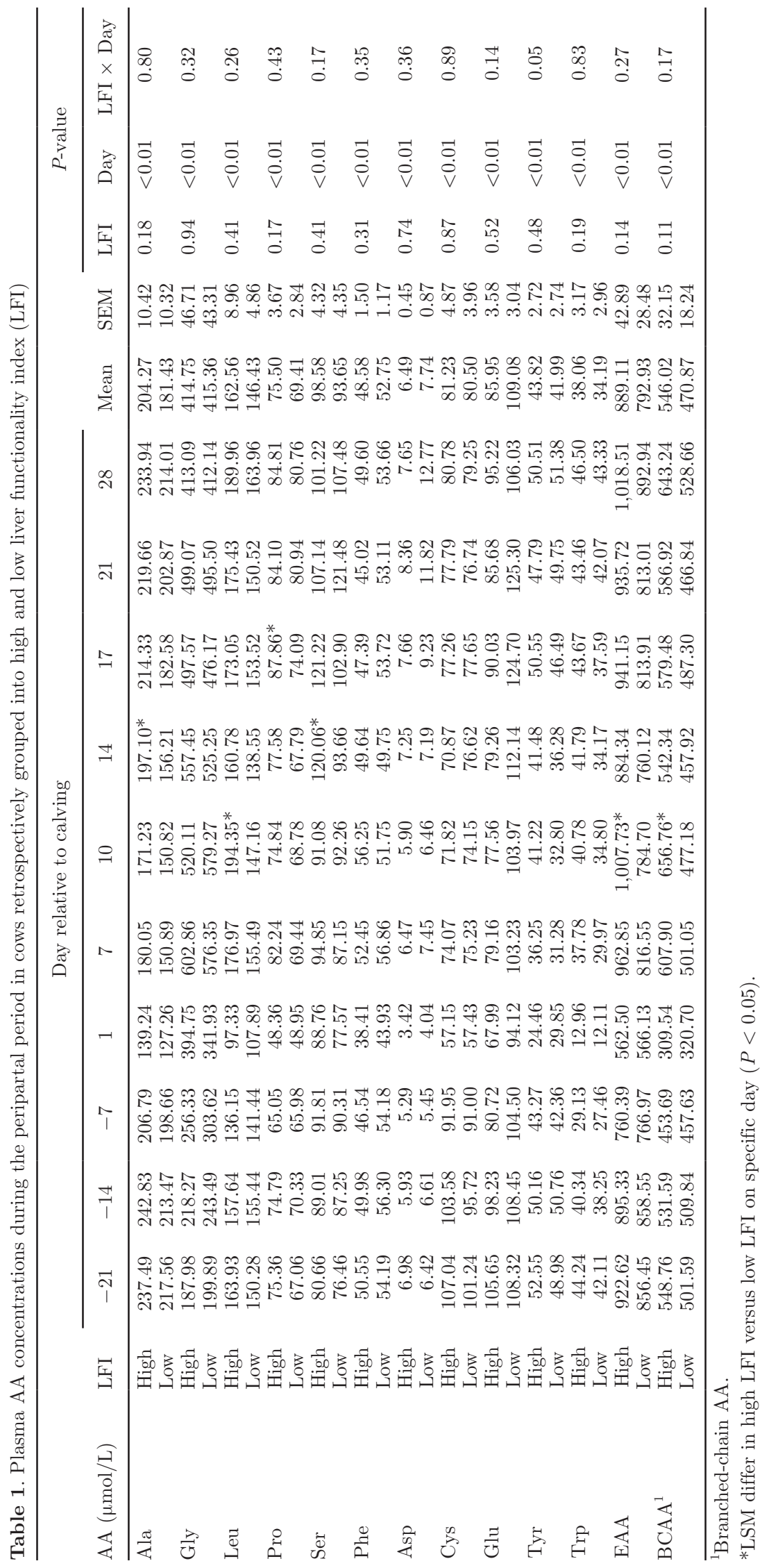



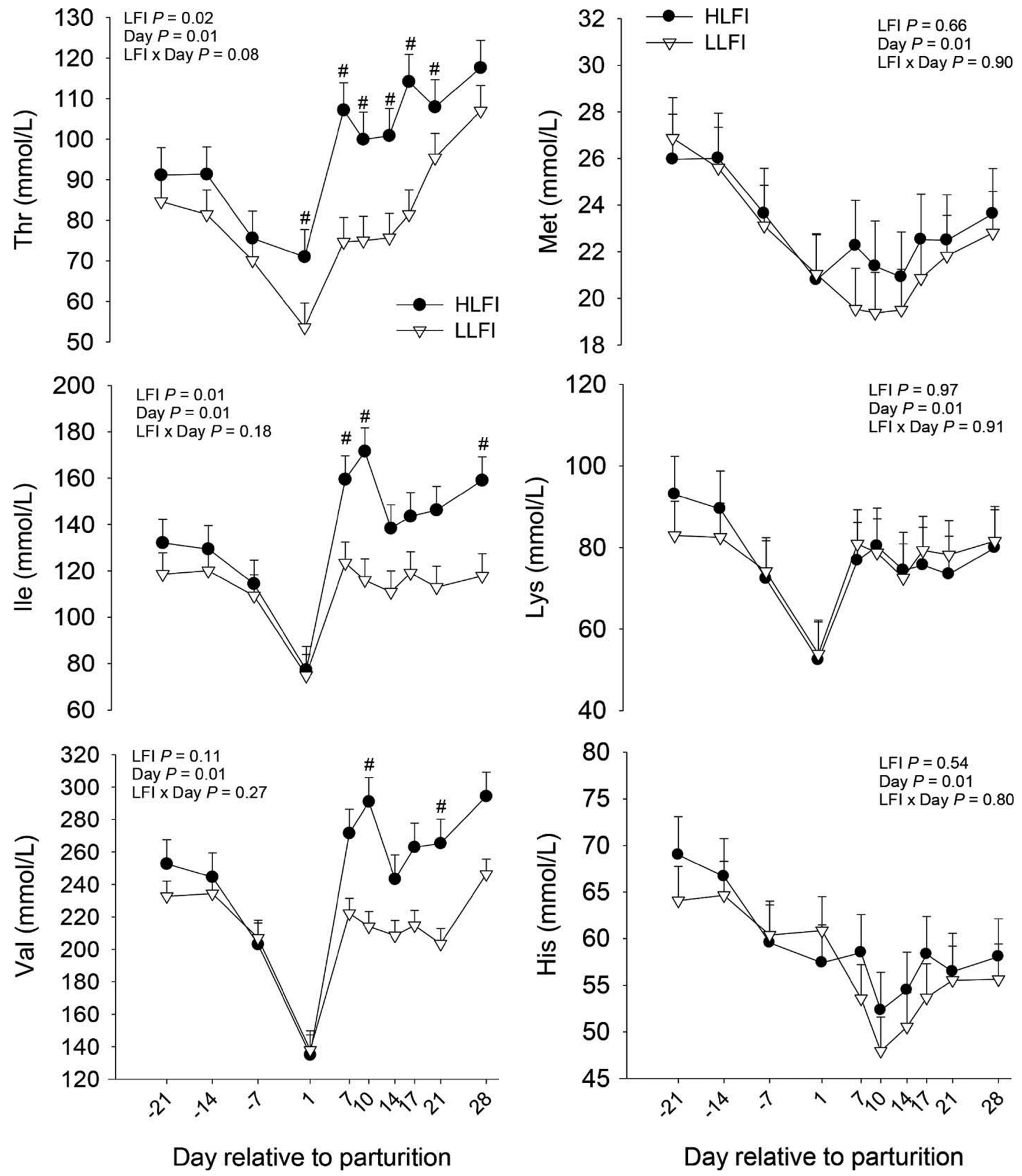

Figure 3. Blood plasma concentrations of Thr, Ile, and Val during the periparturient period in cows retrospectively grouped into high (HLFI) and low (LLFI) liver functionality index (LFI). Values are LSM + SEM. ${ }^{\#}$ LSM tend to differ by $P=0.08$ (LFI $\times$ day).

Figure 4. Blood plasma concentrations of Met, Lys, and His during the periparturient period in cows retrospectively grouped into high (HLFI) and low (LLFI) liver functionality index (LFI). Values are $\mathrm{LSM}+\mathrm{SEM}$. 
of Ser had a significant LFI $\times$ day interaction $\left(P_{\mathrm{LFI}} \times\right.$ day $=0.02$; Table 2), mainly due to higher Ser in HLFI cows on $\mathrm{d} 14$ and 17 . The significant day $\left(P_{\text {day }}<0.01\right)$ effect for Tyr (Supplemental Table S1; http://dx.doi. org/10.3168/jds.2015-9805) concentration was associated with a gradual increase in concentration from calving through d 28 regardless of LFI. A significant LFI $\times$ day interaction $\left(P_{\mathrm{LFI} \times \text { day }}=0.05\right.$, Table 1$)$ was detected for Tyr because of the higher concentration in HLFI cows on d 10 postpartum.

Concentrations of Ala, Leu, Val, Pro, Phe, Asp, Cys, Glu, Lys, and Trp gradually decreased from $-21 \mathrm{~d}$ to calving, reaching a nadir on $\mathrm{d} 1$ postpartum followed by an increase afterward (Table 1; Figure 4). Among these AA, HLFI cows had greater $\left(P_{\mathrm{LFI}}=0.04\right)$ Val concentrations postpartum (Table 2) due to a greater increase in concentration from d 1 to 10, which remained higher through d 28 (Figure 3). Glycine was the only AA that showed an increased concentration progressively through the parturition phase to a maximum at $\mathrm{d} 7$ postpartum, followed by a gradual decrease (Table 1).

Both plasma Met (Figure 4) and Cys (Table 1) decreased markedly between $\mathrm{d}-21$ and calving, after which their concentrations remained unchanged until 14 d postpartum, followed by a gradual increase through $28 \mathrm{~d}$, regardless of LFI. The concentration of Lys decreased from $\mathrm{d}-21$ to calving (Figure 4 ) and thereafter Lys was restored to prepartum values. The plasma His decreased to reach a nadir at d 10 after calving and its concentration was not restored to prepartum levels until d 28 (Figure 4).

\section{DISCUSSION}

\section{Liver Function and LFI}

Although the 2 cohorts of cows in the present study were clinically healthy and maintained a BCS of $\sim 2.8$ before calving, the BHB concentrations postpartum indicated that they were subclinically ketotic for the better part of the first $3 \mathrm{wk}$ postcalving (Supplemental Table S2; http://dx.doi.org/10.3168/jds.2015-9805). Therefore, judging by the longitudinal changes in BCS, BW, and fatty acids, the release of free fatty acids from adipose tissue in these cows might have contributed to the differences in liver function measured through the LFI approach. The usefulness of LFI in assessing liver function during the peripartal period has been demonstrated previously (Trevisi et al., 2010b, 2012). Conventional biomarkers measured in the present study further confirmed previous results. For instance, the greater values of glutamic oxaloacetic transaminase in LLFI cows postpartum indicated more severe liver damage in these cows.

Liver function can be affected by inflammation during the peripartal period (Loor et al., 2013), and it is

Table 2. Plasma concentrations of selected AA during the prepartum and postpartum period in cows retrospectively grouped into high and low liver functionality index (LFI)

\begin{tabular}{|c|c|c|c|c|c|c|c|}
\hline \multirow[b]{2}{*}{$\mathrm{AA}(\mu \mathrm{mol} / \mathrm{L})$} & \multirow[b]{2}{*}{ Stage } & \multicolumn{2}{|c|}{ LFI } & \multirow[b]{2}{*}{ SEM } & \multicolumn{3}{|c|}{$P$-value } \\
\hline & & High & Low & & LFI & Day & LFI $\times$ Day \\
\hline \multirow[t]{2}{*}{$\overline{\mathrm{Val}}$} & Prepartum & 233 & 225 & 18 & 0.76 & $<0.01$ & 0.68 \\
\hline & Postpartum & 252 & 207 & 16 & 0.04 & $<0.01$ & 0.49 \\
\hline \multirow[t]{2}{*}{ Ile } & Prepartum & 125 & 116 & 6 & 0.27 & 0.02 & 0.83 \\
\hline & Postpartum & 142 & 111 & 6.9 & $<0.01$ & $<0.01$ & 0.31 \\
\hline \multirow[t]{2}{*}{ Met } & Prepartum & 25.2 & 25.2 & 1.2 & 0.96 & 0.03 & 0.83 \\
\hline & Postpartum & 22.0 & 20.7 & 1.6 & 0.58 & 0.31 & 0.87 \\
\hline \multirow[t]{2}{*}{ Lys } & Prepartum & 84.9 & 79.9 & 9.6 & 0.67 & $<0.01$ & 0.67 \\
\hline & Postpartum & 73.3 & 75.0 & 7.6 & 0.78 & $<0.01$ & 0.99 \\
\hline \multirow[t]{2}{*}{ Thr } & Prepartum & 86.0 & 78.7 & 5.0 & 0.34 & $<0.01$ & 0.95 \\
\hline & Postpartum & 103 & 80.5 & 5.1 & $<0.01$ & $<0.01$ & 0.31 \\
\hline \multirow[t]{2}{*}{ His } & Prepartum & 65.1 & 63.0 & 2.9 & 0.72 & 0.01 & 0.33 \\
\hline & Postpartum & 53.9 & 56.5 & 3.2 & 0.55 & 0.09 & 0.81 \\
\hline \multirow[t]{2}{*}{ Gln } & Prepartum & 255 & 251 & 29 & 0.82 & 0.55 & 0.68 \\
\hline & Postpartum & 191 & 162 & 25 & 0.28 & 0.81 & 0.13 \\
\hline \multirow{2}{*}{ Ser } & Prepartum & 87.2 & 84.7 & 6.1 & 0.77 & $<0.01$ & 0.87 \\
\hline & Postpartum & 103 & 97.5 & 5.8 & 0.45 & $<0.01$ & 0.02 \\
\hline \multirow[t]{2}{*}{ EAA } & Prepartum & 859 & 827 & 59 & 0.71 & $<0.01$ & 0.68 \\
\hline & Postpartum & 902 & 779 & 41 & 0.04 & $<0.01$ & 0.41 \\
\hline \multirow[t]{2}{*}{$\mathrm{BCAA}^{1}$} & Prepartum & 511 & 490 & 38 & 0.69 & 0.01 & 0.65 \\
\hline & Postpartum & 561 & 463 & 31 & 0.03 & $<0.01$ & 0.19 \\
\hline \multirow[t]{2}{*}{$\mathrm{TAA}^{2}$} & Prepartum & 2,046 & 2,015 & 59 & 0.79 & 0.10 & 0.47 \\
\hline & Postpartum & 2,238 & 2,055 & 52 & 0.02 & $<0.01$ & 0.86 \\
\hline
\end{tabular}


well established that all cows likely experience some degree of inflammation, especially after calving (Bertoni and Trevisi, 2013). Cholesterol, bilirubin, and albumin are expected to respond to an inflammation-induced change in liver function (Bertoni and Trevisi, 2013). Because the pathways of protein synthesis, especially APP, are altered in response to an inflammatory challenge, LFI also may serve as an indicator of potential differences in AA profiles during this period.

\section{LFI and Plasma AA}

There is evidence that fatty liver postpartum in the context of the "fat cow syndrome" is associated with temporal changes in plasma AA concentrations during the peripartal period. In a study using cows with BCS $>4.0$, cows with hepatic lipidosis had greater plasma fatty acids and BHB and lower concentrations of several AA (e.g., Met, Phe, Trp, Arg; Shibano and Kawamura, 2006). Although both cohorts of cows in the present study were subclinically ketotic for a period during early lactation, the concentrations of fatty acids and BHB did not differ in response to LFI. Furthermore, considering that these cows had a BCS $<3.0$ before calving, the gradual increases in fatty acids and BHB postpartum cannot be considered a result of "fat cow syndrome," hence, the observed differences in AA concentrations between HLFI and LLFI cows were caused by other mechanisms; for example, the inflammatory response.

In nonruminants, plasma AA concentrations during inflammation are reduced due to increased extraction by liver for production of APP (Kurpad, 2006; Hashemi, 2013). During the peripartal period, an increase in positive APP (including ceruloplasmin) and a decrease in negative APP (e.g., albumin, lipoproteins) is often observed as a result of inflammation (Trevisi et al., 2010a). In rats experiencing an infectious challenge, the utilization of Thr for synthesis of APP was increased markedly (Faure et al., 2007). As APP have a high content of Phe and Trp (Kurpad, 2006), this may account, in part, for the observed decrease in plasma concentrations of both AA after calving. Therefore, the lower EAA postpartum in LLFI compared with HLFI cows may be a result of the increased demand for APP synthesis in LLFI cows.

In terms of immunity, it has been suggested that the essentiality of BCAA for immune cells also relates to synthesis of APP, immunoglobulins, cytokines, and other proteins (Calder, 2006). In fact, insufficient availability of BCAA prevents an optimal immune response from being mounted (Calder, 2006). Therefore, the higher BCAA in HLFI cows might have been an indication of a better capacity of the immune system to respond to an inflammatory challenge postpartum. The differences in AA profiles in the 2 cohorts of cows suggest that LFI is closely related to systemic AA differences and, therefore, may potentially serve as a diagnostic indicator of AA status, especially when differences in APP are detected.

\section{AA Profiles}

Continuous synthesis and breakdown of proteins characterizes the process of body protein metabolism (Bergen, 2008). Previous studies with dairy cattle proposed that AA profiles in serum are affected by a multitude of events, such as skeletal muscle catabolism (Bell et al., 2000; Korhonen et al., 2002), dietary AA profile (Polan et al., 1991), liver gluconeogenesis, and gastrointestinal absorption (Meijer et al., 1995). In the context of the periparturient period, the increased demand for fetal development prepartum and the inability of cows to consume sufficient protein contribute to negative protein or AA balance, especially when the onset of lactation greatly increases the mammary gland demand for AA (Bell et al., 2000). Recent data from several studies reveals that the uptake of total NEAA by liver is substantially greater in the periparturient period (Kuhla et al., 2011; Larsen and Kristensen, 2013) and these may act as precursors for glucose synthesis.

In the present study, plasma concentrations of most AA decreased close to calving, reached a nadir $1 \mathrm{~d}$ after calving, and gradually increased to prepartum values after $\sim 10 \mathrm{~d}$ into lactation. This pattern is in accordance with previous reports (Verbeke et al., 1972; Meijer et al., 1995; Doepel et al., 2002) and was probably due to the increased requirements for both milk protein synthesis and gluconeogenesis (to support lactose production) coupled with insufficient dietary intake (including a transient decrease in DMI at the time of parturition). This is also in line with the estimated temporal flow of MP reaching the intestine in peripartal cows (Bell et al., 2000).

Previous research has underscored the importance of Met as a limiting AA for milk protein synthesis in many diets (Schwab et al., 1992; Pisulewski et al., 1996). In the present study, the marked decrease of plasma Met level through calving, as well as the failure to restore prepartum values until $28 \mathrm{~d}$ postpartum, suggests that milk production and composition may benefit from Met supplementation during the peripartal period, as demonstrated recently (Osorio et al., 2013). It is noteworthy that another sulfur-containing AA, Cys, followed the same pattern as Met and failed to be restored to prepartal levels, even after $28 \mathrm{~d}$ postpartum. This might be explained by increased uptake of Met by liver during the periparturient period (Larsen and 
Kristensen, 2013), especially because Met is a key component of the one-carbon metabolism pathway and the precursor of sulfur-containing AA including glutathione and taurine, 2 intracellular antioxidants (Kalhan and Marczewski, 2012). Indeed, in order for the immune system to function well, an optimal level of glutathione is required, and even moderate changes in intracellular glutathione level greatly impair lymphocyte function during inflammation (Dröge and Breikreutz, 2000). Therefore, the dependence of glutathione on the availability of Cys and its precursor Met may partly explain the failure of early postpartum dairy cows to restore plasma sulfur-containing AA concentrations, even after $28 \mathrm{~d}$.

Histidine has been suggested as the first-limiting AA for lactating cows when grass silage, barley, and oat diets are fed (Kim et al., 2001; Huhtanen et al., 2002). Similar to Met, the plasma His concentration in the present study did not return to prepartal levels until 28 d postpartum (Figure 4). Using data from the literature and their own, Larsen and Kristensen (2013) reported that the uptake of Met and His, but not Lys, by liver increases between -14 and $+4 \mathrm{~d}$ relative to parturition, which partly explains the lower concentration of both AA in the current study and agrees with the previous observation of greater His metabolism (higher activity of His pyruvate transaminase and His ammonia lyase) in the liver during pregnancy in nonruminants (Makoff and Baldridge, 1964). Because liver uptake of Lys does not increase after parturition, the decrease in plasma Lys is probably the result of net removal by the mammary gland where, besides direct use for milk protein synthesis, it can provide a source of $\mathrm{N}$ for synthesis of other AA (Lapierre et al., 2009). Further research is required to determine the specific reasons for the various responses in plasma concentrations of Met, Lys, and His.

Glycine was the only AA to increase during the periparturient period. The release of Gly is expected to increase as part of any increase in muscle protein breakdown during the periparturient period (Doepel et al., 2002), and it can also be synthesized de novo (Wang et al., 2013). More importantly, there is only limited removal by the mammary gland (Raggio et al., 2006), which would help maintain plasma concentrations during this period of intense metabolic activity. Oxidative degradation of choline during the periparturient period also can produce Gly and simultaneously provides methyl groups for synthesis of Met from homocysteine (Wu et al., 2013). Thus, the high concentration of Gly in plasma may result partly from choline degradation. However, further research is needed to test this possibility.

\section{CONCLUSIONS}

The greater milk yield over time, superior liver function, and more favorable plasma AA profile in HLFI cows indicate a better immuno-metabolic state during the periparturient period. The differences in AA profiles between the 2 cohorts of cows provide evidence that LFI is closely related to systemic AA concentrations and, therefore, may serve as a diagnostic indicator of AA status. Regardless of LFI, most AA concentrations in the circulation reached a nadir just after calving and gradually returned to prepartum values at the end of the transition period. The gradual increase in voluntary DMI may account, in part, for this restoration. Nonetheless, in addition to the intake responses, HLFI cows had greater plasma AA compared with LLFI cows, which might explain their better overall performance and health. Methionine, Cys, and His may be limiting AA in the transition period, as their concentrations did not return to prepartal levels by $28 \mathrm{~d}$ postpartum. Therefore, supplementation with these AA may help improve overall performance and health of dairy cows during the transition period. Whether supplementation with other AA that differed between HLFI and LLFI, such as Thr and BCAA, will also improve production or enhance animal health remains to be tested.

\section{ACKNOWLEDGMENTS}

Zheng Zhou is a recipient of a $\mathrm{PhD}$ scholarship from China Scholarship Council (Beijing, China).

\section{REFERENCES}

AOAC International. 2000. Official Methods of Analysis. 17th ed. AOAC International, 356 Gaithersburg, MD.

Bell, A. W., W. S. Burhans, and T. R. Overton. 2000. Protein nutrition in late pregnancy, maternal protein reserves and lactation performance in dairy cows. Proc. Nutr. Soc. 59:119-126.

Bergen, W. G. 2008. Measuring in vivo intracellular protein degradation rates in animal systems. J. Anim. Sci. 86(Suppl. 14):E3-E12.

Bertoni, G., and E. Trevisi. 2013. Use of the liver activity index and other metabolic variables in the assessment of metabolic health in dairy herds. Vet. Clin. North Am. Food Anim. Pract. 29:413-431.

Bertoni, G., E. Trevisi, X. Han, and M. Bionaz. 2008. Effects of inflammatory conditions on liver activity in puerperium period and consequences for performance in dairy cows. J. Dairy Sci. 91:33003310 .

Bionaz, M., E. Trevisi, L. Calamari, F. Librandi, A. Ferrari, and G. Bertoni. 2007. Plasma paraoxonase, health, inflammatory conditions, and liver function in transition dairy cows. J. Dairy Sci. 90:1740-1750.

Calder, A. G., K. E. Garden, S. E. Anderson, and G. E. Lobley. 1999. Quantitation of blood and plasma amino acids using isotope dilution electron impact gas chromatography/mass spectrometry with U-(13)C amino acids as internal standards. Rapid Commun. Mass Spectrom. 13:2080-2083.

Calder, P. C. 2006. Branched-chain amino acids and immunity. J. Nutr. 136:288S-293S.

Cardoso, F. C., W. Sears, S. J. LeBlanc, and J. K. Drackley. 2011. Technical note: Comparison of 3 methods for analyzing areas un- 
der the curve for glucose and nonesterified fatty acids concentrations following epinephrine challenge in dairy cows. J. Dairy Sci. 94:6111-6115.

Doepel, L., H. Lapierre, and J. J. Kennelly. 2002. Peripartum performance and metabolism of dairy cows in response to prepartum energy and protein intake. J. Dairy Sci. 85:2315-2334.

Drackley, J. K. 1999. ADSA Foundation Scholar Award: Biology of dairy cows during the transition period: The final frontier? J. Dairy Sci. 82:2259-2273.

Dröge, W., and R. Breitkreutz. 2000. Glutathione and immune function. Proc. Nutr. Soc. 59:595-600.

Faure, M., F. Chone, C. Mettraux, J. P. Godin, F. Bechereau, J. Vuichoud, I. Papet, D. Breuille, and C. Obled. 2007. Threonine utilization for synthesis of acute phase proteins, intestinal proteins, and mucins is increased during sepsis in rats. J. Nutr. 137:1802-1807.

Forde, N., C. A. Simintiras, R. Sturmey, S. Mamo, A. K. Kelly, T. E. Spencer, F. W. Bazer, P. Lonergan, and X. Ye. 2014. Amino acids in the uterine luminal fluid reflects the temporal changes in transporter expression in the endometrium and conceptus during early pregnancy in cattle. PLoS ONE 9:e100010.

Grummer, R. R., P. C. Hoffman, M. L. Luck, and S. J. Bertics. 1995. Effect of prepartum and postpartum dietary energy on growth and lactation of primiparous cows. J. Dairy Sci. 78:172-180.

Hailemariam, D., R. Mandal, F. Saleem, S. M. Dunn, D. S. Wishart, and B. N. Ametaj. 2014. Metabolomics approach reveals altered plasma amino acid and sphingolipid profiles associated with pathological state in transition dairy cows. Curr. Metabolomics 2:184-195.

Hashemi, S. 2013. Branched chain amino acid supplementation modulates the effect of inflammatory mediators on the function of a hepatoma cell line. MS Thesis. Rutgers University, New Brunswick, NJ.

Huhtanen, P., A. Vanhatalo, and T. Varvikko. 2002. Effects of abomasal infusions of histidine, glucose, and leucine on milk production and plasma metabolites of dairy cows fed grass silage diets. J. Dairy Sci. 85:204-216.

Hutjens, M. 2010. Benchmarking your feed efficiency, feed costs, and income over feed cost. Adv. Dairy Technol. 22:3-10.

Kalhan, S. C., and S. E. Marczewski. 2012. Methionine, homocysteine, one carbon metabolism and fetal growth. Rev. Endocr. Metab. Disord. 13:109-119.

Kim, C. H., J. J. Choung, and D. G. Chamberlain. 2001. Responses of milk production to the intravenous infusion of amino acids in dairy cows given diets of grass silage and cereal-based supplements. J. Anim. Physiol. Anim. Nutr. (Berl.) 85:293-300.

Korhonen, M., A. Vanhatalo, and P. Huhtanen. 2002. Effect of protein source on amino acid supply, milk production, and metabolism of plasma nutrients in dairy cows fed grass silage. J. Dairy Sci. 85:3336-3351.

Kuhla, B., G. Nurnberg, D. Albrecht, S. Gors, H. M. Hammon, and C. C. Metges. 2011. Involvement of skeletal muscle protein, glycogen, and fat metabolism in the adaptation on early lactation of dairy cows. J. Proteome Res. 10:4252-4262.

Kume, S., S.-i. Araki, N. Ono, A. Shinhara, T. Muramatsu, K. Isshiki, K. Nakamura, H. Miyano, D. Koya, M. Haneda, S. Ugi, H. Kawai, A. Kashiwagi, T. Uzu, H. Maegawa, and M. Oresic. 2014. Predictive properties of plasma amino acid profile for cardiovascular disease in patients with type 2 diabetes. PLoS ONE 9:e101219.

Kurpad, A. V. 2006. The requirements of protein \& amino acid during acute \& chronic infections. Indian J. Med. Res. 124:129-148.

Lapierre, H., L. Doepel, E. Milne, and G. E. Lobley. 2009. Responses in mammary and splanchnic metabolism to altered lysine supply in dairy cows. Animal 3:360-371.

Larsen, M., and N. B. Kristensen. 2013. Precursors for liver gluconeogenesis in periparturient dairy cows. Animal 7:1640-1650.

Loor, J. J., M. Bionaz, and J. K. Drackley. 2013. Systems physiology in dairy cattle: Nutritional genomics and beyond. Annu. Rev. Anim. Biosci. 1:365-392.

Maeda, Y., H. Ohtsuka, and M. Oikawa. 2012. Effect of the periparturient period on blood free amino acid concentration in dairy cows/ healthy cows. J. Vet. Med. Anim. Health 4:124-129.
Makoff, R., and R. C. Baldridge. 1964. The metabolism of histidine. Liver-enzyme changes during development. Biochim. Biophys. Acta 90:282-286.

Mallard, B. A., J. C. Dekkers, M. J. Ireland, K. E. Leslie, S. Sharif, C. L. Vankampen, L. Wagter, and B. N. Wilkie. 1998. Alteration in immune responsiveness during the peripartum period and its ramification on dairy cow and calf health. J. Dairy Sci. 81:585-595.

McCarthy, M. M., S. Manns, D. V. Nydam, T. R. Overton, and J. A. McArt. 2015. Short communication: Concentrations of nonesterified fatty acids and $\beta$-hydroxybutyrate in dairy cows are not well correlated during the transition period. J. Dairy Sci. 98:6284-6290.

Meijer, G. A., J. Van der Meulen, J. G. Bakker, C. J. Van der Koelen, and A. M. Van Vuuren. 1995. Free amino acids in plasma and muscle of high yielding dairy cows in early lactation. J. Dairy Sci. 78:1131-1141.

Osorio, J. S., P. Ji, J. K. Drackley, D. Luchini, and J. J. Loor. 2013. Supplemental Smartamine M or MetaSmart during the transition period benefits postpartal cow performance and blood neutrophil function. J. Dairy Sci. 96:6248-6263.

Piccioli-Cappelli, F., J. J. Loor, C. J. Seal, A. Minuti, and E. Trevisi. 2014. Effect of dietary starch level and high rumen-undegradable protein on endocrine-metabolic status, milk yield, and milk composition in dairy cows during early and late lactation. J. Dairy Sci. 97:7788-7803.

Pisulewski, P. M., H. Rulquin, J. L. Peyraud, and R. Verite. 1996. Lactational and systemic responses of dairy cows to postruminal infusions of increasing amounts of methionine. J. Dairy Sci. 79:1781-1791.

Polan, C. E., K. A. Cummins, C. J. Sniffen, T. V. Muscato, J. L. Vicini, B. A. Crooker, J. H. Clark, D. G. Johnson, D. E. Otterby, B. Guillaume, L. D. Muller, G. A. Varga, R. A. Murray, and S. B. Peirce-Sandner. 1991. Responses of dairy cows to supplemental rumen-protected forms of methionine and lysine. J. Dairy Sci. 74:2997-3013.

Pruessner, J. C., C. Kirschbaum, G. Meinlschmid, and D. H. Hellhammer. 2003. Two formulas for computation of the area under the curve represent measures of total hormone concentration versus time-dependent change. Psychoneuroendocrinology 28:916-931.

Raggio, G., S. Lemosquet, G. E. Lobley, H. Rulquin, and H. Lapierre. 2006. Effect of casein and propionate supply on mammary protein metabolism in lactating dairy cows. J. Dairy Sci. 89:4340-4351.

Schwab, C. G., C. K. Bozak, N. L. Whitehouse, and M. M. Mesbah. 1992. Amino acid limitation and flow to duodenum at four stages of lactation. 1. Sequence of lysine and methionine limitation. J. Dairy Sci. 75:3486-3502.

Shibano, K. I., and S. Kawamura. 2006. Serum free amino acid concentration in hepatic lipidosis of dairy cows in the periparturient period. J. Vet. Med. Sci. 68:393-396.

Trevisi, E., M. Amadori, S. Cogrossi, E. Razzuoli, and G. Bertoni. 2012. Metabolic stress and inflammatory response in high-yielding, periparturient dairy cows. Res. Vet. Sci. 93:695-704.

Trevisi, E., A. Ferrari, F. Piccioli-Cappelli, P. Grossi, and G. Bertoni. 2010a. An additional study on the relationship between the inflammatory condition at calving time and net energy efficiency in dairy cows. EAAP Public 127:489-490.

Trevisi, E., A. Zecconi, G. Bertoni, and R. Piccinini. 2010b. Blood and milk immune and inflammatory profiles in periparturient dairy cows showing a different liver activity index. J. Dairy Res. $77: 310-317$.

Verbeke, R., E. Roets, and G. Peeters. 1972. Variations in the concentrations of free amino acids in the plasma of the dairy cow at parturition. J. Dairy Res. 39:355-364.

Wang, W., Z. Wu, Z. Dai, Y. Yang, J. Wang, and G. Wu. 2013. Glycine metabolism in animals and humans: Implications for nutrition and health. Amino Acids 45:463-477.

Wu, B. T., S. M. Innis, K. A. Mulder, R. A. Dyer, and D. J. King. 2013. Low plasma vitamin B-12 is associated with a lower pregnancy-associated rise in plasma free choline in Canadian pregnant women and lower postnatal growth rates in their male infants. Am. J. Clin. Nutr. 98:1209-1217. 